\title{
Application of Geographic Information System (GIS) to Model the Hydrocarbon Migration: Case Study from North-East Malay Basin, Malaysia
}

\author{
Rudini $^{1,{ }^{*},}$, Abd Nasir Matori ${ }^{1}$, Jasmi Ab Talib ${ }^{2}$, and Abdul-Lateef Balogun ${ }^{1}$ \\ ${ }^{1}$ Civil \& Environmental Engineering Department, University Technology of PETRONAS, Seri \\ Iskandar, 32610 Tronoh, Perak, Malaysia \\ ${ }^{2}$ Petroleum Geoscience Department, University Technology of PETRONAS, Seri Iskandar, 32610 \\ Tronoh, Perak, Malaysia
}

\begin{abstract}
The purpose of this study is to model the migration of hydrocarbon using Geographic Information System (GIS). Understanding hydrocarbon migration is important since it can mean the difference between success and failure in oil and gas exploration project. The hydrocarbon migration modeling using geophysical method is still not accurate due to the limitations of available data. In recent years, GIS has emerged as a powerful tool for subsurface mapping and analysis. Recent studies have been carried out about the abilities of GIS to model hydrocarbon migration. Recent advances in GIS support the establishment and monitoring of prediction hydrocarbon migration. The concept, model, and calculation are based on the current geological situation. The spatial data of hydrocarbon reservoirs is determined by its geometry of lithology and geophysical attributes. Top of Group E horizon of north-east Malay basin was selected as the study area due to the occurrence of hydrocarbon migration. Spatial data and attributes data such as seismic data, wells log data and lithology were acquired and processed. Digital Elevation Model (DEM) was constructed from the selected horizon as a result of seismic interpretation using the Petrel software. Furthermore, DEM was processed in ArcGIS as a base map to shown hydrocarbon migration in north-east Malay Basin. Finally, all the data layers were overlaid to produce a map of hydrocarbon migration. A good data was imported to verify the model is correct.
\end{abstract}

\section{Introduction}

Geographic Information System (GIS) is a system for storing, managing, analyzing, and visual expressing geographic information [1]. GIS develops rapidly as computer information system to collect and manage the space data, then analyze them to make output of vision available [2].

The Oil and Gas industry is driven by an estimated $80 \%$ data that has a spatial component [3]. GIS is able to integrate all the spatial data in addition to manage, inquire,

\footnotetext{
*Corresponding author: rudini.rudi@gmail.com
} 
analyze and visualize data [2]. The different data layers can be integrated statistically, based on data and/or knowledge-driven approaches, to map petroleum potential [4]. GIS can also produce more accurate output spatial and attribute information. Due to its impressive capabilities, GIS is able to meet the specified requirements in oil and gas industry [2].

Understanding hydrocarbon migration is important since it can mean the difference between success and failure in oil and gas exploration project. In recent years, the use of advanced geophysical methods has become standard in the reservoir characterization. The flow direction of hydrocarbon can be predicted and visualized with modeling hydrocarbon migration. However, many of existing methods are not suitable for large geographical areas of exploration. The hydrocarbon migration modeling using geophysical method is not particularly accurate because of the limitations of available data, since the seismic exploration has limited data covering.

With recent advances in GIS technology, it is possible to establish more accurate migration of hydrocarbon modeling. New studies have been carried out about the abilities of GIS to model migration of hydrocarbon. GIS-Based algorithm was successfully applied for modeling secondary migration of hydrocarbon in Songliao Basin, China [5]. Therefore, the purpose of this study is to model hydrocarbon migration using GIS in North-East part of Malay Basin. The objective of this study is to assess migration of hydrocarbon in NorthEast Malay Basin using GIS software.

\section{Geological Setting}

Malay basin is located in east peninsular Malaysia, between latitude $4^{\circ}-8^{\circ} \mathrm{N}$ and longitude $102^{\circ}-106^{\circ}$ E. Its size is $500 \mathrm{~km}$ long and $200 \mathrm{~km}$ wide with more than $12 \mathrm{~km}$ sediment thickness in basin center [6]. It is located between Penyu and West Natuna Basin to the south and the Pattani Basin to the north as shown in Fig. 1.

The basin is formed during late Eocene-Oligocene to earliest Miocene as a result of tectonic activities in the basin. There are three main phases of tectonic activities in the basin; extensional synrift, thermal subsidence and compressional inversion (Fig. 2). The extensional synrift phase occurred during pre-Miocene era. This caused the basin to pull downward and created normal fault in the Malay Basin. The thermal subsidence occurred during early Miocene. At this phase, the basin is near to sea level, which is proven by the abundance of coal bearing strata interbedded in sand-shale deposition. The process of thermal subsidence is still on going. The last phase is basin inversion, which occurred in middle Miocene era and seems to have continued well in the Pliocene. The basin inversion has resulted in regional uplift and titling of southern part towards the northwest whereby the anticline structure is created from the downward extensional pulling and reactivated the major bonding faults [6].

Most of structural evolution of the southern Malay Basin has been relatively favorable to oil generation and entrapment [6]. Fault trending in Malay Basin can be divided into two parts. At the southeastern (SE) part, the faults are trending in EW and NW-SE directions while at the northwestern (NW) part the faults are trending in N-S direction as shown in Fig. 3.

Malay Basin comprises with two petroleum systems; there are Oligocene-Miocene Lacustrine Total Petroleum System with lacustrine shale source and reservoir and Oligocene-Miocene Lacustrine Total Petroleum System with coal and coaly shale source and fluvial, deltaic, near shore marine and offshore marine bar reservoirs and divided into two groups which are Group H and Group I. The Group I petroleum system is consist of mostly gas system which resulted by Group E and D when reached generation phase of the time of anticlinal traps were form. The major reservoir of Group I system are sands in the 
shallower unit. Vertical migration of hydrocarbon is the dominant mechanism for charging the relatively shallow reservoir since the Group I source rocks are structurally deeper in basin. Sub-vertical basement-linked fault acted as conduits for hydrocarbon migration. These gases are also like migrate into stratigraphically equivalent formation on the flank. The Group H Petroleum System derives its hydrocarbon from Group H source rock. The location of Group $\mathrm{H}$ oil kitchen indicated that the potential traps in Group D, E and B overlying it should be filled with oil. Group $\mathrm{H}$ oil is more likely to be preserved on the basin margins where it may migrate laterally via carrier beds. Hence, the main reservoirs for the Group $\mathrm{H}$ petroleum system would be in the fault-related traps at the basin margins [6].

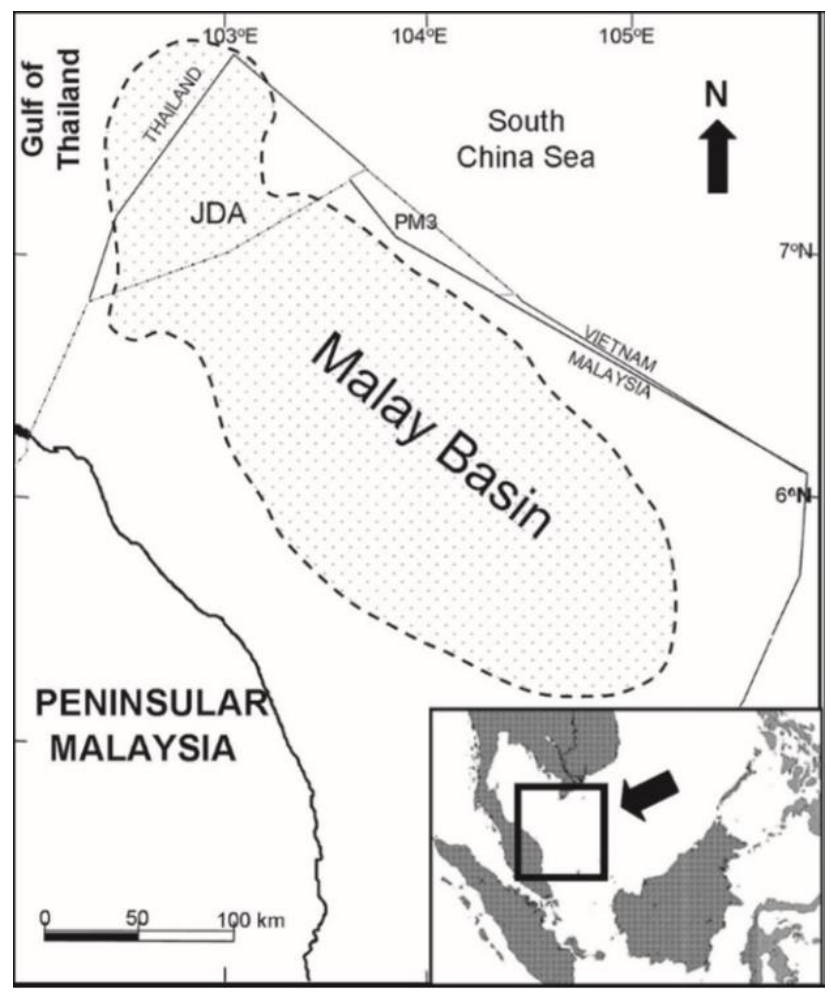

Fig. 1. Location of Malay Basin in South East Asia (inset) [6].

\section{Methodology}

The concepts, model and calculation of the development of a petroleum system are based on the current geological situation. The current geometry of the lithology and geophysical attributes are determining the current spatial distribution of the hydrocarbon reservoirs. For these reasons, accurate, correct and structure integration of all petroleum-related data and analysis as well as interpretation to model the petroleum environment is crucial to the result of hydrocarbon migration modeling. 


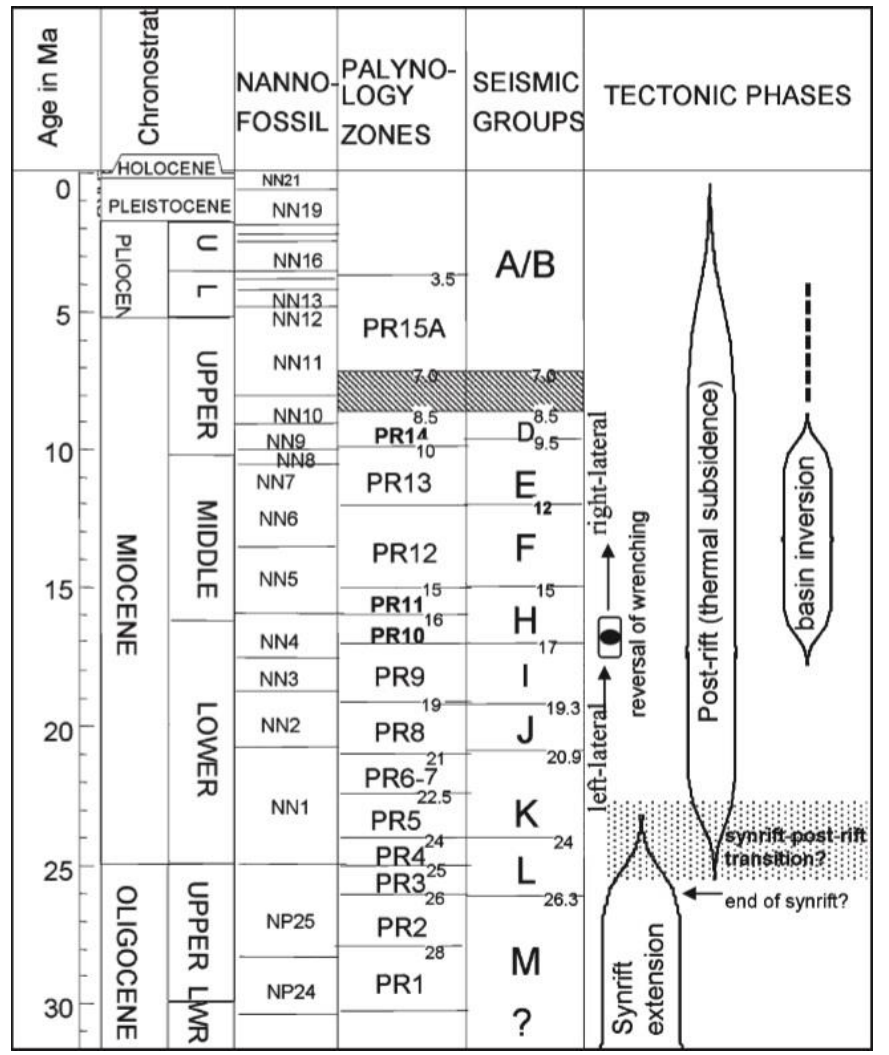

Fig. 2. Stratigraphy of Malay Basin [6].

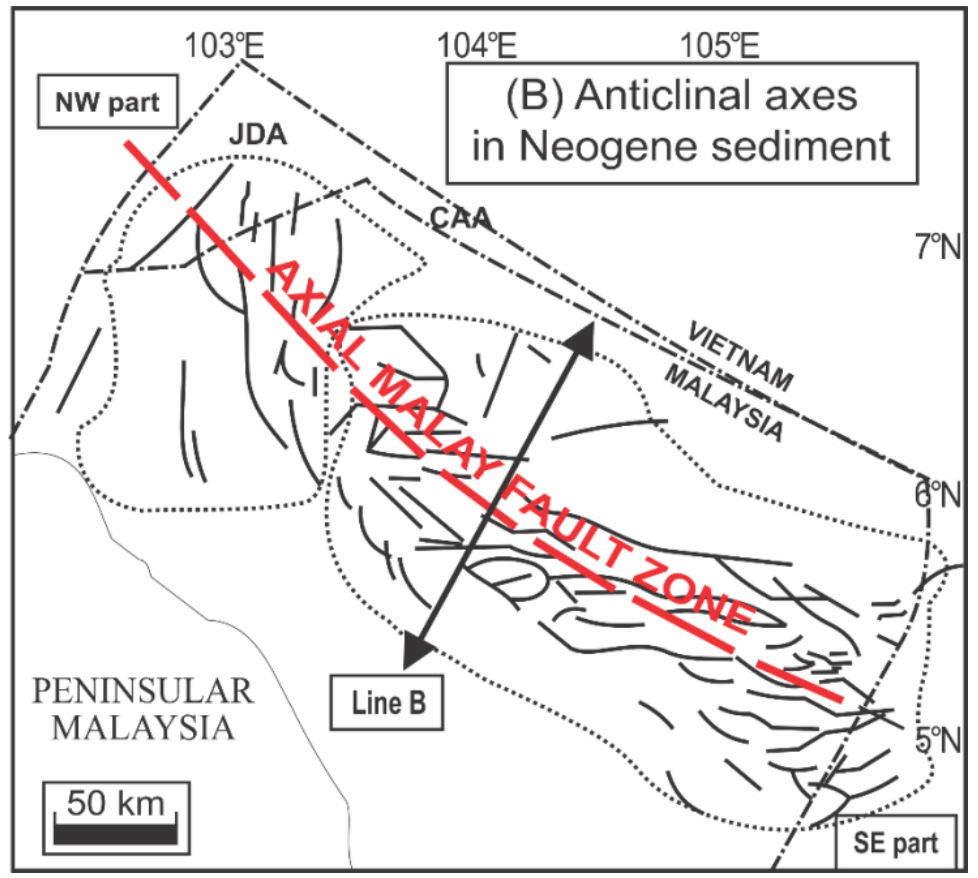

Fig. 3. Fault direction in Malay Basin; the dotted boundaries represent NW and SE part of the Basin [modified from 7]. 
The methodology includes data preparation, data processing in petrel and ArcGIS and visualization. Seismic data, geological data and lithology data were collected for data preparation (Fig. 4). In petrel, Seismic data was interpreted and top of Group E horizon was selected as a basemap before it was exported to ArcGIS for advance processing. The process of searching for hydrocarbon migration is similar to the surface water flow concept. The difference lies in mechanisms and flow direction. The water flow direction is downward because it is driven by gravity force. Meanwhile, the flow direction of hydrocarbon migration is upward because it is driven by buoyancy and capillary pressure [5]. Based on this principle Digital Elevation Model (DEM) was constructed to stimulate the hydrocarbon migration modeling. DEM of Group E horizon was constructed by the result of seismic interpretation in ArcGIS software. Spatial analyst tool such as hydrology tool and 3D analyst tool were used in modeling hydrocarbon migration. Furthermore, 2Dimensional Map of hydrocarbon migration was produced. In the end, well log data was imported to ArcGIS as an attribute data.

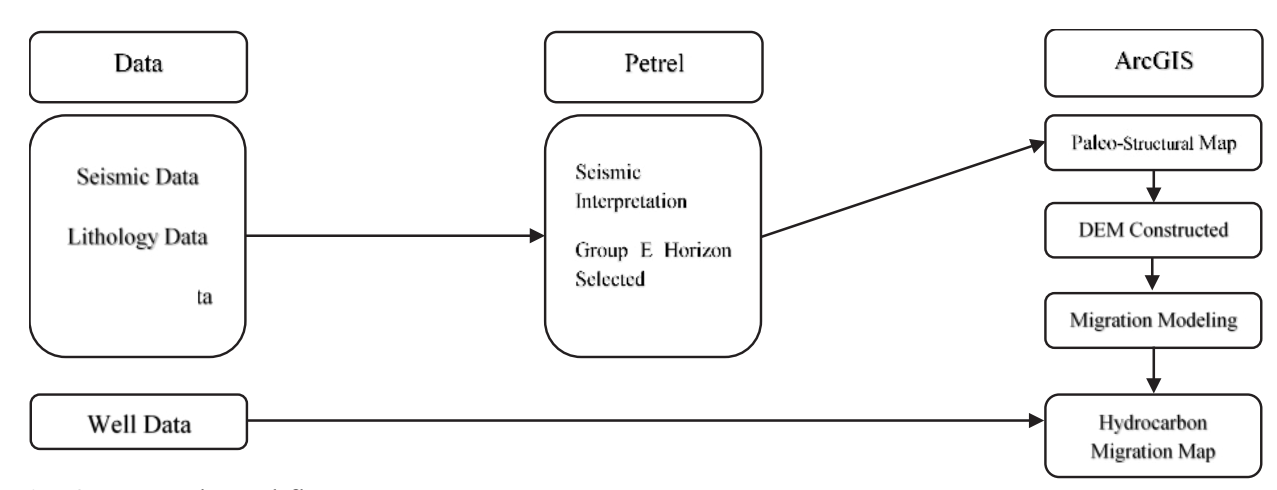

Fig. 4. Research workflow.

\section{Results and discussions}

Seismic data was interpreted in Petrel Software. Top of Group E horizon was selected as paleo-structural map and exported to ArcGIS software as a basemap for advance processing. In ArcGIS software DEM was constructed from paleo-structural map of Top of Group E horizon to start hydrocarbon migration modeling. Using spatial analyst tool and 3D analyst tool to create model of hydrocarbon migration (Fig. 5).

Fig. 6 shows the migration pathway in the northeast Malay basin, Malaysia from top of Group E formation horizon. The elevation of top of Group E horizon is between 1261 meters to 1692 meters below seafloor. The migration pattern indicates upward movement to highest elevation from lowest elevation. Hydrocarbon accumulated is accumulated in 1350 to 1400 meters below seafloor. Well data was imported to show the location of well and to verify the model is correct. Top of Group E horizon was chosen because the hydrocarbon migrated from lower group and accumulated in group E. 


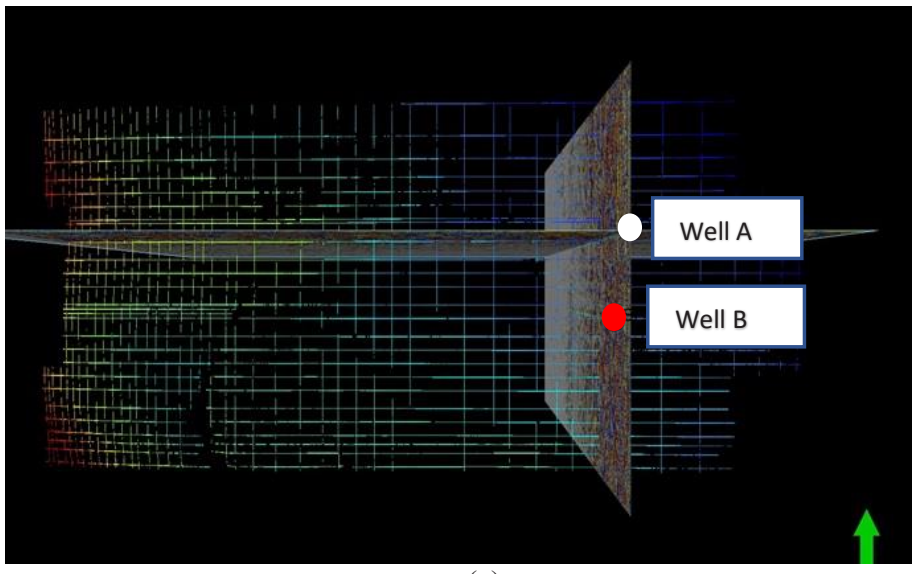

(a)

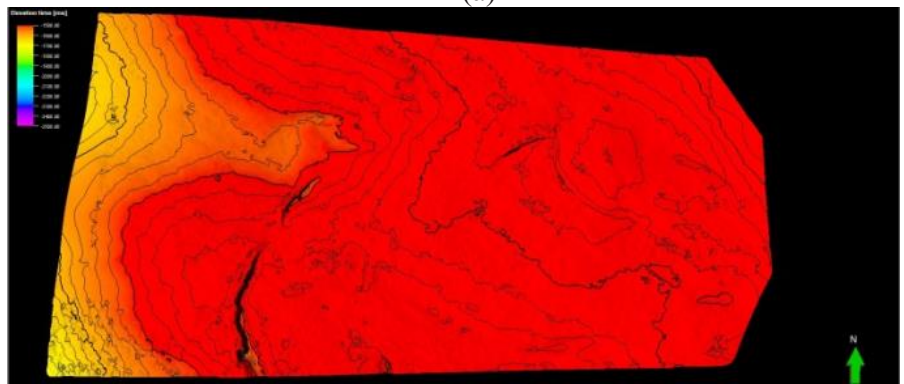

(b)

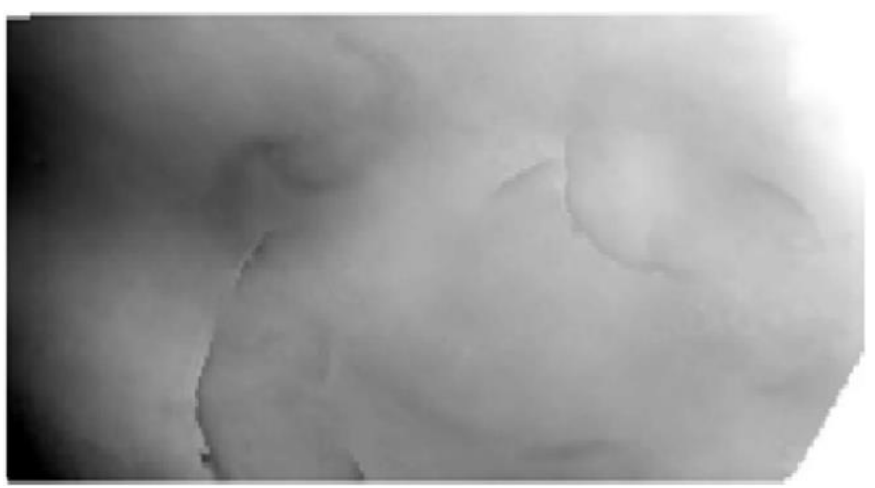

(c)

Fig. 5. Seismic data interpretation (a), Top of Group E horizon paleo-structural map (b) and Digital Elevation Model (DEM) of Top of Group E horizon (c). 


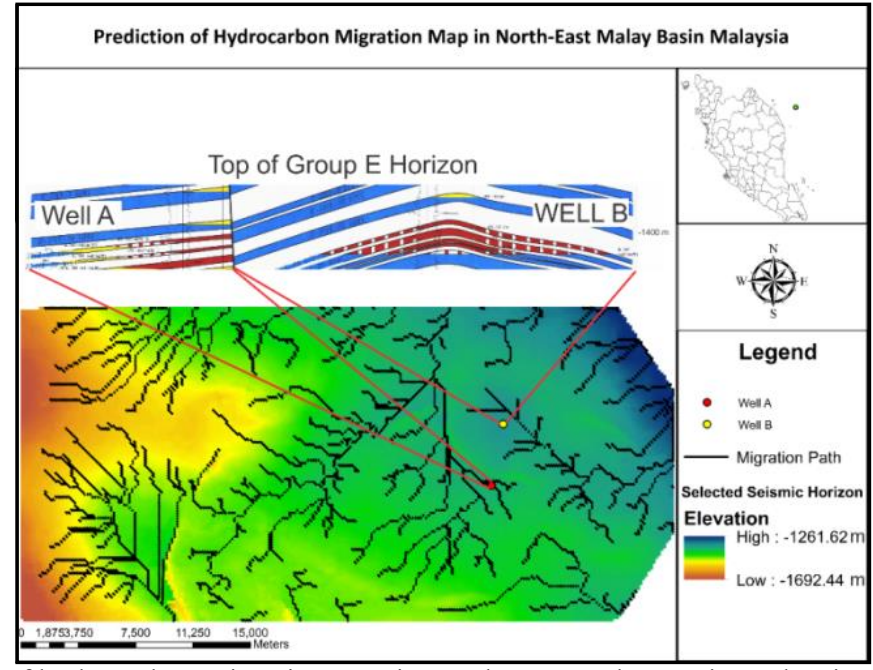

Fig. 6. Prediction of hydrocarbon migration map in North-East Malay Basin Malaysia.

\section{Conclusions}

GIS was successfully applied to modeling hydrocarbon migration in northeast part of Malay Basin, Malaysia. The hydrocarbon migration is matched with previous study about North-East part of Malay basin. The result shows that with current abilities and advantages of GIS, it is possible to successfully apply GIS to hydrocarbon migration modeling in oil and gas industry.

Thanks to University Technology of Petronas (UTP) to give me the opportunity to study this area.

\section{References}

1. D. J. Maguire, 1 (1991)

2. L. Wei, Qinyan, , ESIAT, (2010)

3. S. Deogawanka. https://www.gislounge.com/gis-in-oil-and-gas/ (2016)

4. E. J. M. Carranza, Delft University of Technology, (2002)

5. X. Liu, G. Zhong, J. Yin, Y. He, X. Li, Comp. Geosci. 34 (2008)

6. M. Madon, Y. Jiu-Shan, P. Abolins, A. Redzuan, M. Azmi, Z. S. Bahari, Geo. Soc. of Malay. Bull 49 (2006)

7. M. Madon, P. Abolins, M. J. Hoesni, M. Ahmad (1999) 